\title{
THE MODERATING ROLE OF EXTERNAL ENVIRONMENT ON THE RELATIONSHIP BETWEEN RESOURCE ISOLATING MECHANISM AND SUSTAINABLE COMPETITIVE ADVANTAGE
}

\author{
Purity W. Ndegwa, James M. Kilika, Stephen M. A. Muathe \\ Department of Business Administration, Kenyatta University, Nairobi, Kenya
}

\begin{abstract}
Dynamic changes in the firm's external environment influence the future direction of the firm. The operations of the firm are affected by the striking advances in globalization such as shifts in technology, stiff competition among business entities and new entrances within an industry. The firms including commercial banks in Kenya should therefore, have the ability to predict future trends in the external environment for survival. The main purpose of this study was to establish the moderating role of external environment on the relationship between resource isolating mechanism and sustain competitive advantage among commercial banks in Kenya. Descriptive and explanatory research design was employed in the study. The research targeted all the commercial banks in Kenya. Purposive sampling was used to select a sample of 160 respondents from the key departments of Finance, Sales and Marketing, Strategy and Operations of all the forty (40) commercial banks' headquarters in Nairobi, Kenya. The data collection instrument used was semi-structured questionnaire. The variable characteristics were summarized using descriptive statistics. Agreement to the most frequent responses to the statements on the study variables ranged between moderate and high extent. Based on results of hypotheses testing, external environment have no moderating effect on the relationship between resource isolating mechanism and sustainable competitive advantage.
\end{abstract}

Key word: Resources, Isolating Mechanism, Competitive Advantage, Sustainable Competitive Advantage, External Environment.

Cite this Article: Purity W. Ndegwa, James M. Kilika, Stephen M. A. Muathe, The Moderating Role of External Environment on the Relationship Between Resource Isolating Mechanism and Sustainable Competitive Advantage, International Journal of Management, 10 (3), 2019, pp. 50-59.

http://iaeme.com/Home/issue/IJM?Volume=10\&Issue=3 


\section{INTRODUCTION}

The concept of sustainable competitive advantage arising from both resource isolating mechanism and resource capability is an input that requires an entity to consider its external forces (Meyer, 2009). This should be in line with both theoretical and empirical literature that give complementarities between the RBV approach and the institutional perspectives to the study of organizations in addressing their competitiveness (Kilika, 2012). The forces in the external surrounding of the business can influence the entity's strategies, future direction of the firm and the business situation within an industry (Thompson, Strickland \& Gamble, 2007). Changes in technology and government regulations affect the future direction of the firm (Ndegwa, Kilika \& Muathe, 2018).

Dynamic changes in the environment are very fast in creating new opportunities and threats, therefore, firms must determine which factors in the environment present opportunities and the ones which create threats for greater accomplishment of the firm's objectives and strategies (Prasad, 2010; Cole 1997). The environmental analysis provides the company's real situation that is, whether it is healthy or unhealthy (Thompson, Strickland \& Gamble, 2007). Competitive advantage relates to the firm's ability to match internal capabilities and strengths with the opportunities available in the industry and external environment (Grant, 2010). Firms should combine firm's complimentary resources and innovation to yield sustained competitive advantage (Hazen and Byrd, 2012).

Striking advances in globalization, and the external business environment such as shifting of social values, technology, changes in labour force among other shifts have created a challenging environment for organization's day to day operations (Daft, 2012). This is attributed by pressures as a result of stiff competition among rival firms and new entrances in a particular industry (Thompson, Strickland \& Gamble, 2007). Management should therefore be able to predict demand for products or services in their respective markets in order to produce quality products and services that meet consumers demand (Barney, 2007).

Effective management executives should be able to understand the importance of existing external environment to make important strategic decisions (Sababu, 2015). Organizational change is therefore required in order to maintain equilibrium between various external and internal forces to achieve organizational goals (Prasad, 2010). Firms should consider incorporating sustainability of competitive advantage in their business strategy due to external environmental forces and consumer changing demands (Iberg, 2015), for changes in the external environment can create opportunities and threats for a firm and dictates the types of products to be developed (Rothaermel, 2008; David, 2013).

Increased political and regulatory framework have made the banking sector to experience serious challenges which are associated with global uncertainty (Barclays PLC Annual report, 2014). Internal forces emanating from stakeholders and external forces resulting from the government pressures, customers, competitors, NGOs and the society within the banking industry force banks to integrate daily sustainability practices and corporate policies (Jeucken \& Bouma, 1999). All the banks are required to maintain a minimum liquidity ratio and cash reserves with Central Bank of Kenya (Cytonn, 2016). The main objective of this study therefore, was to determine the moderating role of external environment on the relationship between resource isolating mechanism and sustainable competitive advantage among commercial banks in Kenya.

The findings of this study provides insight to the managements of the banks and other sectors on the importance of external environment in sustainability of competitive advantage. The study findings can also be used by the government and policy makers in the developing nations in development of strategies. The study contributed towards filling of the information gap on the subject matter which is useful for future research. The study also contributed to the 
existing body of knowledge, which can be used as reference point by academicians, scholars and researchers.

\section{LITERATURE REVIEW}

The section specifically reviews conceptual and empirical literature in view of pointing out research gaps and highlights the existing theories in regard to management characteristics explored by scholars. The study sought to establish the moderating role of external environment on the relationship between resource isolating mechanism and sustainable competitive advantage.

Institutional theory of organizations emerged from Philip Selznick in 1948, whereby he noted that organizations have their own life cycle and are created to achieve goals. Institutional theory model views organizational structures as a means of shaping the organization's characteristics in response to the changes in the external environment (Tosi, 2009). Institutional theory of organizations provides a multifaceted view of firms and argues that firms are predisposed by normative pressures, from either internal or external sources (Zucker, 1987). It is a concept that best captures the process of homogenization and this enable the characteristics of the organization to be modified in the right direction which is compatible with the characteristics of the external environment (DiMaggio \& Powell, 1983). From an institutional perspective, the most important aspect of isomorphism interaction with environmental institutions is the evolution of organizational language (Meyer \& Rowan, 1977).

Institutionalization is a process concerned with creation of social reality whereby there are social orders in an organization and each individual actors takes action (Tosi, 2009). Institutionalized products or services, techniques, policies, and programs and function are powerful myths (Meyer \& Rowan, 1977). Institutions have cultural or discursive dimensions and also structural or organizational ones (Meyer, 2007). Organizations that omit environmental legitimated elements of structure or create unique structures lack acceptable legitimated accounts of their activities (Meyer \& Rowan, 1977). Institutional isolating mechanism can also be involuntary and exogenous and exist when otherwise accessible resources and capabilities that support a competitive advantage are rejected if they fail to fit with prevailing cultural norms or political interests (Oliver, 1997).

Srivastava, Franklin, and Martinette, (2013) sought to analyze cross-industrial best practices and future trends in the context of the contemporary resource based competitive advantage model of the firm. The study used online survey within a typical Hi-Technology company. Thirty three questions requiring graded or multiple-choice answers was issued to respondents. The main aim for the questionnaires was to collect data on the quantitative assessment or relative feedback in areas considered to play very important role in building or sustaining a firm's competitive advantage. The findings indicated that high-tech firms sustainable competitive advantage was dependent on agility and customer centric approach further, engagement of new employees improved market viability and an investment in the necessary infrastructure to secure a deeper level of mutual trust with the firm's key customers.

The study concluded that longer-term perspective in building resources and capabilities that has entry barriers against competitors were essential for firms. In the long run such barriers would ensure the few players are exposed to opportunities, among them technology which ensure high business margin and security of sustainable competitive advantage. Once attained, these higher levels of trust and differential technology can open up opportunities of maintaining a higher margin business and so securing a sustained competitive advantage. The study also found that there are other forces in the firm's external environment such as globalization, digitilization, partnerships, joint ventures and de-regulations which creates barriers for companies to compete effectively. From the result findings, the study recommended for future 
research on this area in order to gain a deeper understanding of the relative influence of these factors on a firm's ability to remain competitive in the longer term (Srivastava, Franklin, \& Martinette, 2013).

Ong and Ismail (2008), study sought to establish the relationship between information technology competence and sustainable competitive advantage, where the focus of the study was on the resource based view on SMEs in Malaysia. The unit of analysis was SMEs whereby data was collected through various methods from the selected sample. A total of 2572 personal emails were sent to respondents of which 1575 successfully reached the respondents but only 152 respondents responded. The study established that there existed a relationship between information technology competence and sustainable competitive advantage. The study further recommended that firms continuously renew their ICT competencies to sustain the competitive advantage of the firm.

\section{Conceptual Framework}

The conceptual framework on figure 1, illustrates the direction of the relationship between study variables: Resource isolating mechanism, external environment and sustainable competitive advantage.

\section{Independent Variables}

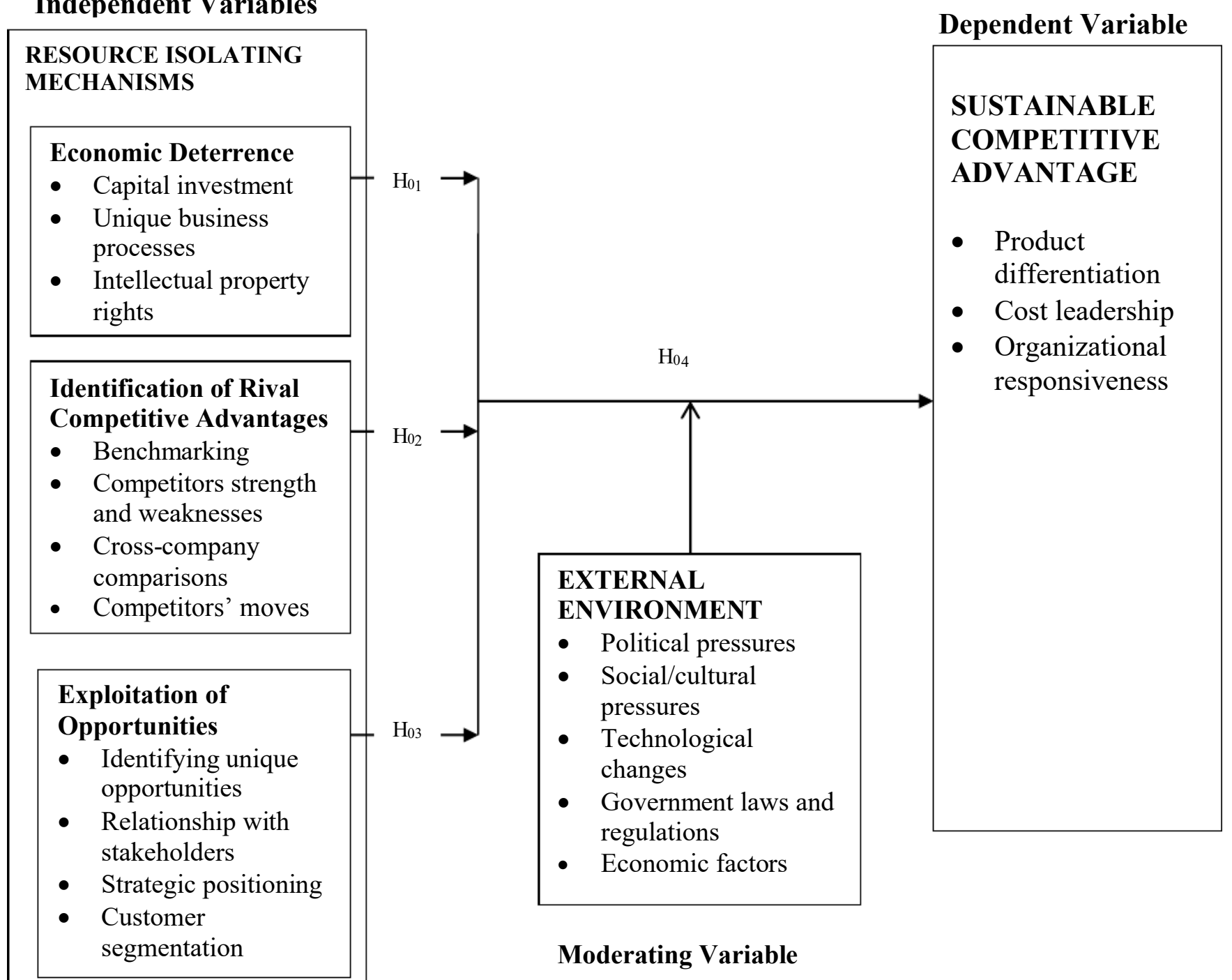

Figure 1 Schematic Diagram (Source: Author (2017) 


\section{RESEARCH METHODOLOGY}

This study used descriptive research design and explanatory research design. Descriptive research design enable the researcher to ascertain and describe the characteristics of the variables Sekaran (2003). According to (Kothari, 2009), explanatory research design further builds on the descriptive design and enables further discussion on causal effects of the variables under study

The population of this study was all 40 commercial banks in Kenya and the respondents were managers of key departments at their headquarters in Nairobi, Kenya. The study used primary data which was collected using semi-structured questionnaire which contained both open-ended and close-ended questions. The research instruments was validated in terms of content and face validity. The researcher measured the reliability of the questionnaire to determine its consistency. The results of reliability analysis showed that the Cronbach Alpha was 0.728 for external environment. The closer Cronbach's alpha is to 1 , the higher the internal consistency (Sekaran, 2003; Weiner \& Hopkins, 2007). As a rule of the thumb, reliability value of 0.7 and above is recommended for it showed reliability of the instrument (Robert, 2006).

Quantitative methods, data analysis involved computation of both descriptive and inferential statistics using Statistical Package for Social Sciences (SPSS). The research hypothesis was tested at $95 \%$ level of confidence in order to provide for drawing of conclusions that if the p-value is less than 5\%, the null hypothesis was rejected and the alternative hypothesis was accepted. If p-value was greater than $5 \%$, the null hypothesis was not rejected and the alternative hypothesis was rejected. Pearson's product movement correlation (r) was derived to show the nature and strength of the relationship. Coefficient of determination $\left(r^{2}\right)$ was used to measure the amount of variations in the dependent variable explained by the relationship between variables.

Moderation effects explained how external environment influenced the relationship between resource isolating mechanism and sustainable competitive advantage. Significance of the effects of the moderating variable was determined from the corresponding p-values. Consequently, the p-values was used to test hypothesis. Moderation test involved determining whether the coefficient for the interaction term was significant.

\section{FINDINGS AND DISCUSSION}

This section presents the study findings which include the bio-data of the study responses, the descriptive analysis and the inferential analysis of the study. A total of 160 questionnaires were administered to respondents who comprised of managers of selected departments in all 40 commercial banks in Kenya. 129 dully filled questionnaires were collected from respondents a response rate of $80.63 \%$. Most of the respondents were experienced, skilled and knowledgeable since they had worked in the bank for more than three years. Also the academic qualifications of most respondents was of degree category implying that they were in a position of interpreting research questions.

Table 1 Variable Characteristics

\begin{tabular}{|c|c|c|c|c|}
\hline Variable & No of Items & $\alpha$ Score & Mean & $\begin{array}{c}\text { Standard } \\
\text { Deviation }\end{array}$ \\
\hline Economic deterrence & 129 & 0.856 & 3.91 & 0.81 \\
\hline Identification of rival competitive advantage & 129 & 0.888 & 3.97 & 0.80 \\
\hline Exploitation of opportunities & 129 & 0.841 & 4.21 & 0.70 \\
\hline External Environment & 129 & 0.728 & 3.61 & 0.92 \\
\hline Sustainable competitive advantage & 129 & 0.905 & 3.94 & 0.82 \\
\hline Overall score & & 0.844 & 3.93 & 0.81 \\
\hline
\end{tabular}


The Moderating Role of External Environment on the Relationship Between Resource Isolating Mechanism and Sustainable Competitive Advantage

The moderating variable of the study was external environment. The variable was measured using seven indicators. The statements on external environment had a mean of 3.61 showing that the respondents agreed to the statements on external environment to a moderate extent. The aggregate standard deviation was 0.92 indicating a low variation on the respondents' responses.

\subsection{Test of Hypothesis}

The hypothesis of study was:

There is no significant moderating effect of external environment on the relationship between resource isolating mechanism and sustainable competitive advantage among commercial banks in Kenya.

The hypothesis testing was conducted in three steps where: The first step was to establish regression analysis of the composite of independent variables and the dependent variable. The second step was the establishment of regression analysis of external environment and sustainable competitive advantage and the third step was establishment of regression analysis of the moderated relationship of resource isolating mechanism, external environment and sustainable competitive advantage.

Step 1: Conducting a simple regression analysis of composite of resource isolating mechanism affecting sustainable competitive advantage.

Table 2 Regression analysis for relationship between resource isolating mechanism and sustainable competitive advantage

\begin{tabular}{|c|c|c|c|c|c|c|c|c|c|}
\hline \multicolumn{10}{|c|}{ Model Summary ${ }^{b}$} \\
\hline Model & $\mathrm{R}$ & R Square & \multicolumn{3}{|c|}{ Adjusted R Square } & \multicolumn{2}{|r|}{$\begin{array}{l}\text { Std. Error of the } \\
\text { Estimate }\end{array}$} & \multicolumn{2}{|c|}{ Durbin-Watson } \\
\hline 1 & $.755^{\mathrm{a}}$ & .570 & \multicolumn{3}{|c|}{.567} & \multicolumn{2}{|r|}{.43545} & \multicolumn{2}{|c|}{2.088} \\
\hline \multicolumn{10}{|c|}{ ANOVA $^{\mathrm{a}}$} \\
\hline \multicolumn{2}{|c|}{ Model } & \multicolumn{2}{|c|}{ Sum of Squares } & $\mathrm{df}$ & \multicolumn{2}{|c|}{ Mean Square } & $\mathrm{F}$ & \multicolumn{2}{|c|}{ Sig. } \\
\hline \multirow{3}{*}{1} & Regression & \multicolumn{2}{|c|}{31.984} & 1 & \multicolumn{2}{|c|}{31.984} & 168.677 & \multicolumn{2}{|c|}{$.000^{\mathrm{b}}$} \\
\hline & Residual & \multicolumn{2}{|c|}{24.081} & $12^{\prime}$ & \multicolumn{2}{|c|}{.190} & & & \\
\hline & Total & \multicolumn{2}{|c|}{56.065} & 128 & & & & & \\
\hline \multicolumn{10}{|c|}{ Coefficients $^{\mathrm{a}}$} \\
\hline & & & \multicolumn{4}{|c|}{ Unstandardized Coefficients } & $\begin{array}{l}\text { Standardized } \\
\text { Coefficients }\end{array}$ & $\mathrm{t}$ & Sig. \\
\hline Model & & & \multicolumn{2}{|c|}{$\mathrm{B}$} & \multicolumn{2}{|c|}{ Std. Error } & Beta & & \\
\hline \multirow[b]{2}{*}{1} & \multicolumn{2}{|c|}{ (Constant) } & & .397 & \multicolumn{2}{|c|}{.275} & & 1.443 & .151 \\
\hline & \multicolumn{2}{|c|}{$\begin{array}{c}\text { Resource isolating } \\
\text { mechanism }\end{array}$} & & .878 & \multicolumn{2}{|c|}{.068} & .755 & 12.988 & .000 \\
\hline
\end{tabular}

Source: Survey data (2017)

In step one, the constant $\left(\beta_{0}\right)$ was 0.397 . Indicating that if all factors remained constant, a unit increase in resource isolating mechanism would result to 0.397 unit increment in sustainable competitive advantage. However, the constant was non-significant at $\mathrm{p}>0.05$.

The established equation was:

$$
\mathrm{SCA}=0.397+0.755 \mathrm{RIM}+\varepsilon
$$

Where:

SCA - Sustainable competitive advantage

RIM - Resource isolating mechanism 
This indicates a positive relationship between resource isolating mechanism and sustainable competitive advantage. Resource isolating mechanism had a strong positive relationship with competitive advantage sustainability at $\mathrm{p}=0.00$. The model was fit at $\mathrm{F}=168.77 ; \mathrm{p}=0.00$.

Step 2: Conducting a simple regression analysis with external environment affecting sustainable competitive advantage

Table 3 Regression analysis for relationship between external environment and sustainable competitive advantage

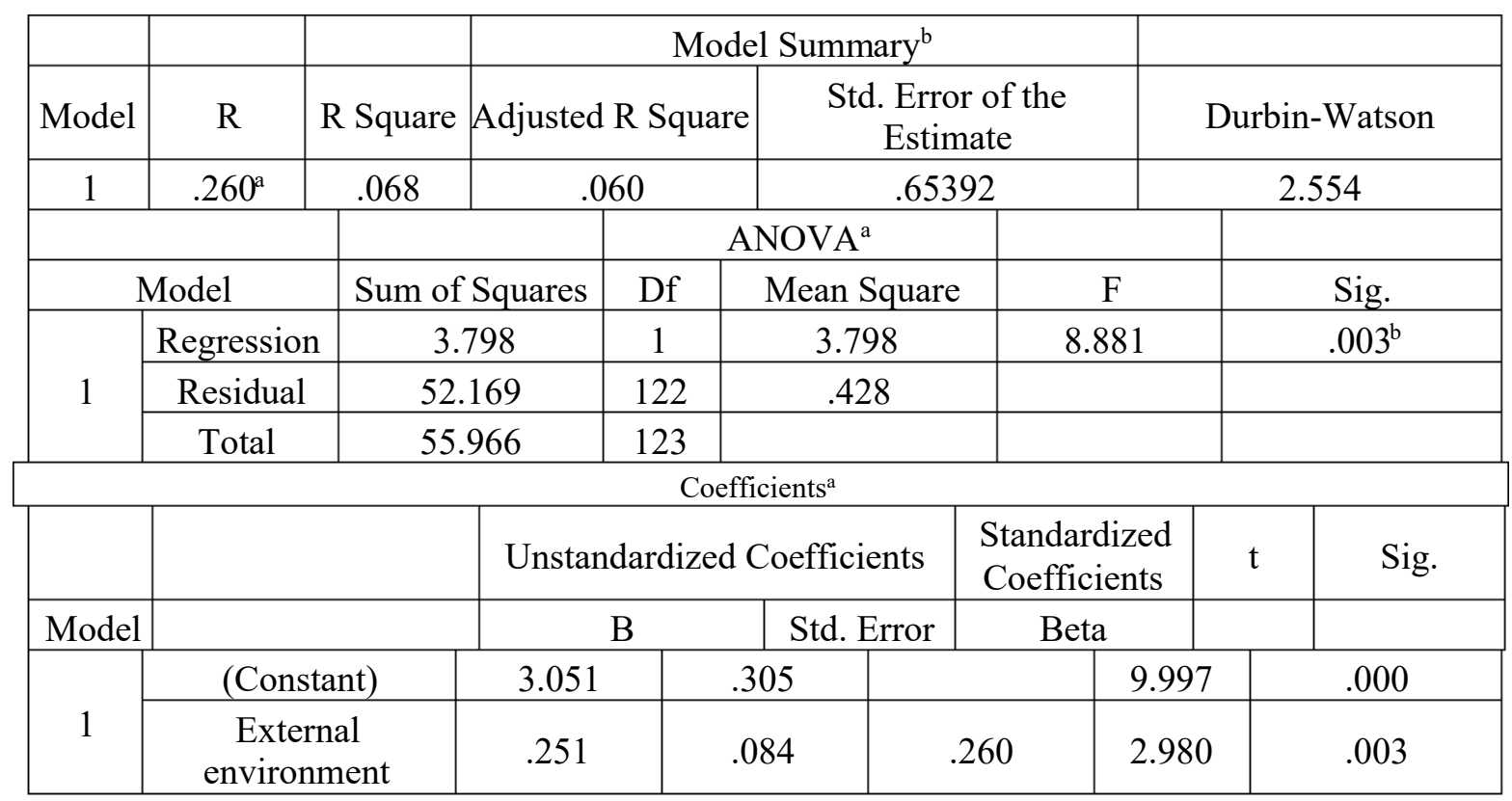

Source: Survey data (2017)

In step two, the constant $\left(\beta_{0}\right)$ was 3.051, indicating that if all factors remained constant, a unit increase in external environment would result to 3.051 unit increment in sustainable competitive advantage. The constant was significant at $\mathrm{p}=0.00$.

The established equation was:

$$
S C A=3.051+0.260 E E n v+\varepsilon
$$

Where:

SCA - Sustainable competitive advantage

EEnv - External environment

This indicates a strong positive $(+\mathrm{ve})$ relation between external environment and competitive advantage sustainability at $\mathrm{p}<0.05$. The model was fit at $\mathrm{F}=8.881 ; \mathrm{p}<0.05$.

Step 3: Conducting a regression analysis with resource isolating mechanism and external environment affecting Sustainable competitive advantage

Table 4 Regression analysis for moderated relationship between resource isolating mechanism, external environment and sustainable competitive advantage

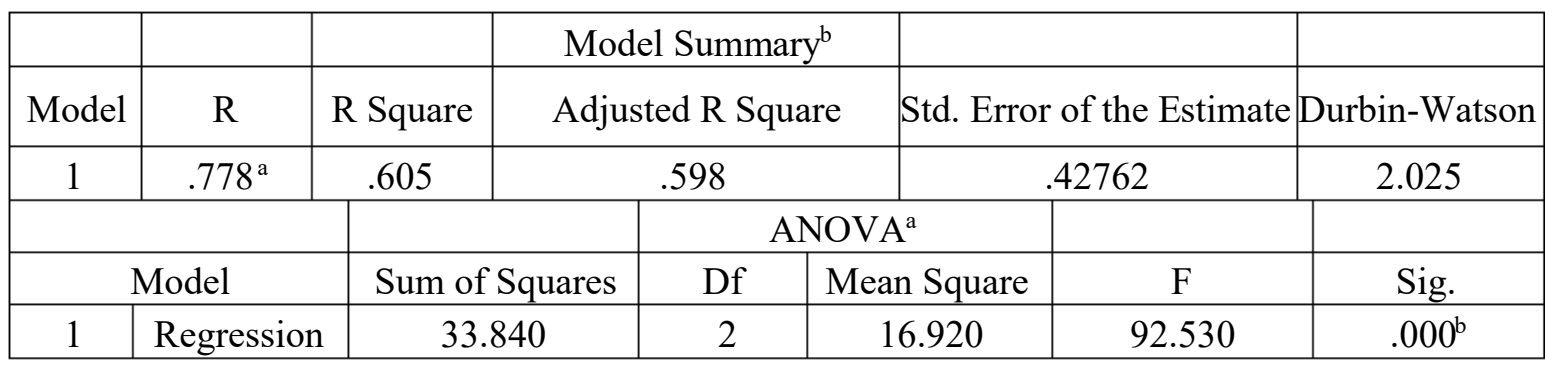


The Moderating Role of External Environment on the Relationship Between Resource Isolating Mechanism and Sustainable Competitive Advantage

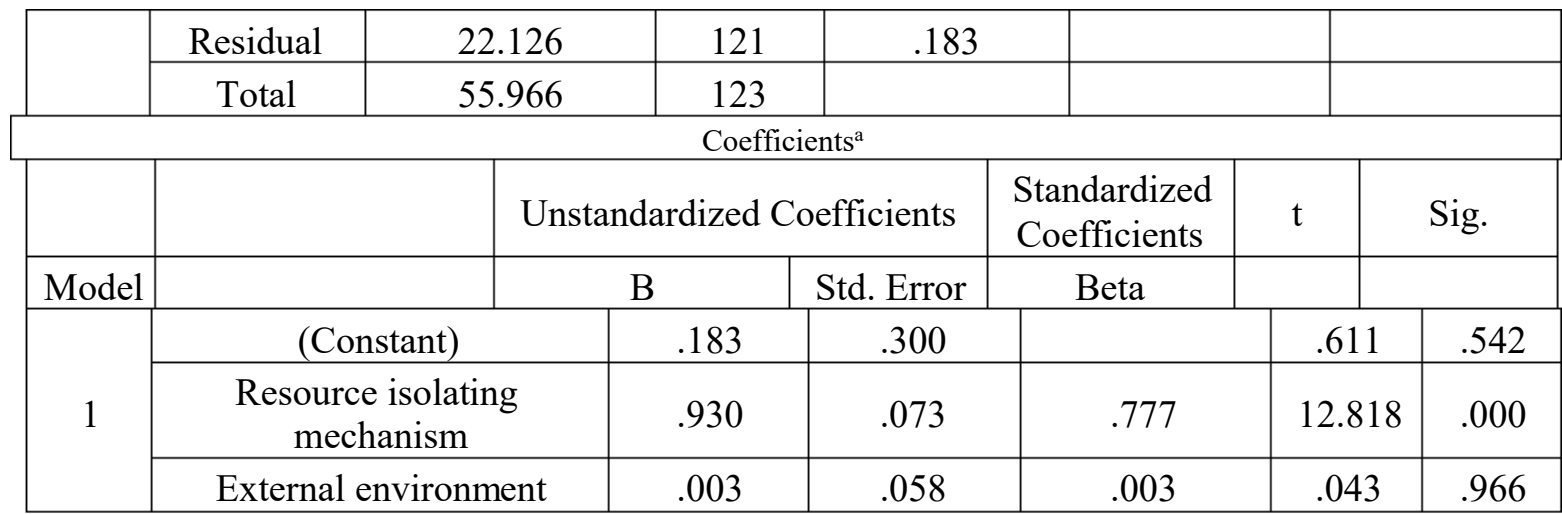

Source: Survey data (2017)

In step three, the constant $\left(\beta_{0}\right)$ was 0.183 , indicating that if all factors remained constant at zero, sustainable competitive advantage would increase by 0.183 units. The constant was nonsignificant at $\mathrm{p}=0.542$.

The established equation was:

$$
\mathrm{SCA}=0.183+0.777 \mathrm{RIM}+0.003 \mathrm{EEnv}+0.022(\mathrm{RIM} * \mathrm{EEnv})+\varepsilon
$$

Where:

SCA - Sustainable competitive advantage

RIM - Resource isolating mechanism

EEnv - External environment

This indicates a positive relationship between resource isolating mechanism and sustainable competitive advantage at $p<0.05$. There was however no relationship between external environment and sustainable competitive advantage.

Table 4.25 Summary of moderated relationship between resource isolating mechanism, external environment and sustainable competitive advantage

\begin{tabular}{|l|c|l|l|c|c|}
\hline Parameter & $\begin{array}{l}\text { Model 1: } \\
\text { Direct } \\
\text { Relationship }\end{array}$ & $\begin{array}{l}\text { Model 2: } \\
\text { Moderator } \\
\text { Relationship }\end{array}$ & $\begin{array}{l}\text { Model 3: } \\
\text { Moderated } \\
\text { Relationship }\end{array}$ & P Value & Change \\
\hline$\beta$ RIM & 0.755 & & 0.777 & 0.000 & 0.022 \\
\hline$\beta$ External environment & & 0.260 & 0.003 & 0.966 & 0.26 \\
\hline R square & 0.570 & 0.068 & 0.605 & & 0.035 \\
\hline$\beta$ Constant & 0.397 & 3.051 & 0.183 & 0.000 & -.241 \\
\hline F & 168.677 & 8.881 & 92.530 & 0.000 & -76.147 \\
\hline
\end{tabular}

Source: Researcher (2017)

Table 4 presents the summary of the moderating effect of external environment on the relationship between resource isolating mechanism and sustainable competitive advantage. From the above summary of findings, the work of external environment on the relationship between resource isolating mechanism and sustainable competitive advantage reduces by 0.022 units. The strength of the relationship ( $\mathrm{r}$ square) increases by $3.5 \%$. The model was fit at $\mathrm{F}=113.058 ; \mathrm{p}<0.05$. When index of independent variable was regressed against the dependent variable the resulting $R^{2}$ is 0.570 and $\beta=0.755$. When the index of the independent variable was introduced when the moderating variable is present, the $\mathrm{R}^{2}$ becomes 0.068 and the $\beta$ RIM becomes 0.260 , when the index of the independent variable, the moderator variable and the subject variable are regressed the $\mathrm{R}^{2}$ becomes 0.605 and the $\beta$ RIM becomes 0.777 . 
The moderating effect is positive; however, it is non-significant. As a result the null hypothesis was supported and it was therefore reasoned out that external environment has no moderating effect on the relationship between resource isolating mechanism and sustainable competitive advantage. However from the study finding, external environment variable was found to be an explanatory variable. According to Fairchild and MacKinnon (2009), moderator is said to be an explanatory variable if the coefficient changes from significance to nonsignificance. From the several bases, external environment has not been used to test moderation, however the study adds contribution that external environment has the role of explanatory variable in the relationship between resource isolating mechanism and sustainable competitive advantage.

\section{CONCLUSION AND IMPLICATION}

The study sought to establish the moderating effect of external environment on the relationship between resource isolating mechanism and sustainable competitive advantage. The study findings established that external environment has no moderating influence on the relationship between resource isolating mechanism and sustainable competitive advantage.

Based on the descriptive findings, technological factors and government regulations scored highly as compared to other indicators of external environment. This implies that the ability of commercial banks to implement resource isolating mechanism is explained by technological factors and government regulations. Cultural and religious factors, social factors, level of unemployment and inflation are other factors that have a explanatory effect but is of little impact among commercial banks in Kenya. Management cognition theory supports that timely adjustment of mental models by top management enables linkage between the external environment and organization strategy. Hence organization renewal and understanding of this environment facilitates decision making and resource allocation. Where the external environment is uncontrollable and hence adjustment on the forces ensures firm sustainability in competitive environment.

The current study findings on external environment is supported by previous findings such as Srivastava et al., (2013); Ong et al., (2008) which found out that technological aspect of firms and long-term perspective in building resources from immediate environment were strong determinants of sustainable competitive advantage. Ong and Ismail (2008) study found that information technology competence of the entrepreneur yields sustainable competitive advantage of the firm where continued competence results to increased sustainable competitive advantage.

\section{RECOMMENDATIONS FOR FUTURE RESEARCH}

The current study found that external environment has no moderating effect on the relationship between resource isolating mechanism and sustainable competitive advantage. Instead, it was found to have explanatory effect. The study therefore, recommends further study on variable external environment with different indicators.

\section{REFERENCES}

[1] Barclays Plc, Barclays Bank (K) Annual Report 2014.

[2] Barney, J. B., \& Hesterly, W. S., Strategic Management and Competitive Advantage, Concepts and Cases. 2nd Edition, New Jersey: Pearson Prentice-Hill, 2008

[3] Cole, G. A., Strategic Management, 2nd Edition. UK: South-Western Cengage Learning, 1997

[4] Cytonn Investment, Kenya Listed Commercial Banks Cytonn Q1 Banking Sector Report Abridged Version, 2016 
The Moderating Role of External Environment on the Relationship Between Resource Isolating Mechanism and Sustainable Competitive Advantage

[5] Daft, R. L., New Era of Management, 10th Edition. USA: Thomsom South-Western, 2012

[6] David, F. R., Strategic Management, Concepts and Cases, Fourteenth Edition. New Jersey: Pearson Prentice Hall, 2013

[7] DiMaggio, P.J., \& Powell, W.W, the Iron Cage Revisited: Institutional Isomorphism and Collective Rationality in Organizational Fields. American Sociological Review, 48(2), 1983, pp 147-160.

[8] Tatiana A. Salimova, Lyudmila I. Biryukova Alvina T. Shilkina and Elena V. Khakhaleva, Towards a Methodology of Sustainable Competitiveness of Organization, International Journal of Civil Engineering and Technology, 9(11), 2018, pp. 161-172

[9] Grant, R. M., Contemporary Strategy Analysis, Text and Cases, Seventh Edition. UK: John Wiley \& Sons Ltd. Publications, 2010

[10] Hazen, B., \& Byrd, T., Toward Creating Competitive Advantage with Logistics Information Technology, International Journal of Physical, Distribution and Logistics Management, 42(1), 2012, pp 8-35.

[11] Iberg, A. E., Creating Competitive Advantage in the Premium Market Segment through a Sustainability Strategy, 2015

[12] Jeuken, M. H. A., \& Bouma, J. J., the Changing Environment of the Banks. Articles, GMI 27, 1999

[13] Kilika, J.M, Institutional context, collaboration, human resource development infrastructure and performance of universities in Kenya. Unpublished Ph. D Thesis. School of Business, University of Nairobi, 2012

[14] Meyer, J. W., Reflection on Institutional Theories of Organizations. SAGE Publications Ltd, 2007

[15] Meyer, J. W., \& Rowan, B., Institutionalized Organizations: Formal Structure as Myth and Ceremony. American Journal of Sociology, 83(2), 1977

[16] Ndegwa, P. W., Kilika, J. M. \& Muathe, S. M., Resource Isolating Mechanisms and Sustainable Competitive Advantage among Commercial Banks in Kenya. European Scientific Journal, 14(34), 2018, ISSN: 1857-7881

[17] Oliver, C.,Sustainable Competitive Advantage: Combining Institutional and ResourceBased Views.Strategic Management Journal, 18:9, 1997, pp 697-71.

[18] Ong, J. W., \& Ismail, H. B., Sustainable Competitive Advantage through Information Technology Competence: Resource-Based View on Small and Medium Enterprises, Communications of the IBIMA, 1, 2008.

[19] Prasad, L. M., Strategic Management. Educational Publishers, New Delhi, 2010

[20] Rothaermel, F. T.,Technological Innovation: Generating Economic Results Advances in the study of Entrepreneurship, Innovation and Economic Growth, Elsevier Ltd, 18, 2008, (201225)

[21] Sababu, B. M., Governance and Strategic Management. Analytical Approach, second edition. The Jomo Kenyatta Foundation, Nairobi, 2015

[22] Srivastava, R. K., Shervani, T.A., \& Fahey, L, Market-based Assets and Shareholder Value: A Framework for Analysis, Journal of Marketing, 62, January, 1998, pp 2-18.

[23] Thompson, A. A., Strickland, A. J., \& Gamble, J. E., Crafting and Executing Strategy. The Quest for Competitive Advantage, Concepts and Cases, 15th Edition. McGraw-Hill, 2007

[24] Green Innovation Capability as Driver of Sustainable Competitive Advantages and SMEs Marketing Performance, Elia Ardyan, Andri Nurtantiono, Budi Istiyanto, Ginanjar Rahmawan. International Journal of Civil Engineering and Technology, 8(8), 2017, pp. $1114-1122$.

[25] Tosi, H. L., Theories of Organization. SAGE Publications, Inc, 2009

[26] Zuker, L. G.,Institutional Theories of Organization. Annual Review of Sociology 13(443464), 1987 